\title{
Geneza i okoliczności konfliktu G. Juliusza Cezara z L. Korneliuszem Sullą
}

\begin{abstract}
Abstrakt: Artykuł poświęcony jest wczesnemu etapowi życia G. Juliusza Cezara — jego powiązaniom rodzinnym, nominacji na kapłana Jowisza i sojuszowi z obozem cynno-mariańskim. Analizowane są w nim także okoliczności i konsekwencje sporu, do jakiego doszło między Cezarem a L. Korneliuszem Sullą w początkowym okresie dyktatury sullańskiej.
\end{abstract}

Słowa kluczowe: Cezar, Sulla, proskrypcje, konflikt, dyktatura

1 listopada 82 roku $^{1}$ L. Korneliusz Sulla rozgromił wojska mariańsko-samnickie w pobliżu Bramy Kollińskiej i tym samym przypieczętował swoje zwycięstwo w pierwszej wojnie domowej. Wymusił mianowanie go dyktatorem i natychmiast przystąpił do represji wymierzonych we wrogów, wśród których było wielu przedstawicieli mariańskiej elity. W celu powstrzymania niekontrolowanego terroru kazał ogłosić listy proskrypcyjne, na których znalazły się nazwiska osób wyjętych spod prawa. Za głowy proskrybowanych wyznaczono nagrody, a ich majątki skonfiskowano ${ }^{2}$. Tym samym Sulla nie tylko mścił się na swoich przeciwnikach, lecz także fizycznie ich eliminował, chcąc zapobiec uformowaniu się ewentualnej opozycji wobec działań naprawczych, którymi planował objąć republikę. Rozdając zaś swoim zwolennikom różne stanowiska oraz skonfiskowane ma-

\footnotetext{
${ }^{1}$ Wszystkie daty w tekście artykułu odnoszą się do czasów przed narodzeniem Chrystusa.

${ }^{2}$ O proskrypcjach sullańskich zob. T.R.S. Broughton, The Magistrates of the Roman Republic, vol. 2, New York 1952, s. 69 (źródła), a także: C. Lanzani, Lucio Cornelio Silla dittatore, Milano 1936, s. 5-25, 93-121; L. Canfora, Proscrizioni e dissesto sociale nella repubblica Romana, „Klio” 1980, 62, s. 425-438; F. Hinard, Les proscriptions de la Rome républicaine, Paris-Roma 1985, s. 17-223; J. Henderson, Sulla's List: The First Proscription, „Parallax” 2003, 9, s. 39-47; P. Madejski, Sullańskie proskrypcje a zemsta w Rzymie, w: Świat starożytny. Państwo i społeczeństwo, red. R. Kulesza, M. Stępień, E. Szabat, M. Daszuta, Warszawa 2013, s. 239-247.
} 
jątki, wiązał ich z nowym reżimem i tworzył w ten sposób uzależnioną od niego elitę władzy ${ }^{3}$.

Wśród osób, które Sulla chciał pozyskać do swego obozu, znalazł się także młody, zaledwie osiemnastoletni wówczas, Gajusz Juliusz Cezarł. Obciążały go co prawda koneksje z G. Mariuszem i L. Korneliuszem Cynną - ciotka Cezara, Julia, była wdową po Mariuszu, zaś córka Cynny, Kornelia, była żoną Cezara ${ }^{5}$, niemniej Sulla był skłonny mu wybaczyć. Rozkazał jedynie, aby rozwiódł się z Kornelią, ale Cezar odmówił. Wywołało to ostrą reakcję dyktatora, który skonfiskował majątek Kornelii, a Cezar, obawiając się o swoje życie, musiał uciekać z Rzymu. Schronił się w kraju Sabinów, został tam jednak odnaleziony przez oddział sullański dowodzony przez niejakiego Korneliusza Fagitę ${ }^{6}$. Młodzieńcowi udało się ponoć go przekupić i dzięki temu ocalić życie. Jednocześnie w Rzymie bliscy uciekiniera przebłagali Sullę, aby mu przebaczył. Dyktator zgodził się, wypowiadając jednak profetyczne słowa, że w Cezarze drzemie wielu Mariuszów. Ułaskawiony młodzieniec udał się na Wschód, gdzie zdobywał pierwsze szlify wojenne pod wodzą Minucjusza Termusa i Serwiliusza Watii. Do Rzymu powrócił dopiero po śmierci Sulli.

Celem niniejszego artykułu jest przyjrzenie się okolicznościom sporu Sulli z Cezarem i zbadanie, na ile był to rzeczywisty konflikt, a na ile kreacja pisarzy antycznych.

Wspomniany epizod relacjonowany jest skromnie przez autorów starożytnych. Piszą o nim jedynie dwaj biografowie Cezara: Plutarch z Cheronei ${ }^{7}$ i Swetoniusz ${ }^{8}$, oraz historyk - Wellejusz Paterkulus ${ }^{9}$. Swetoniusz korzystał zapewne z jakiejś biografii Cezara, których wiele powstało po jego śmierci, mogły to być np. dzieła G. Oppiusza albo L. Korneliusza Balbusa, mógł też ewentualnie czerpać informacje z twórczości Kw. Eliusza Tuberona czy Tytusa Liwiusza. Plutarch w pierwszych rozdziałach biografii Cezara nie cytuje swoich źródeł, ale istnieją przesłanki, by sądzić, że korzystał z biografii Cezara napisanej przez wspomnianego Oppiusza ${ }^{10}$.

${ }^{3}$ Zob. wykaz sullańskiej elity sporządzony przez A. Keaveneya (A. Keaveney, Who were the Sullani?, „Klio” 1984, 66, s. 114-150).

${ }^{4}$ Cezar urodził się 12 lipca 100 roku. Próby przesuwania tej daty na 102 lub 101 rok nie znajdują obecnie uznania w nauce. Zob. E. Badian, From the Iulii to Caesar, w: A Companion to Julius Caesar, ed. M. Griffin, [Blackwell Publishing] 2009, s. 16.

${ }^{5}$ F. Münzer, Cornelia (413), w: Real-Encyclopädie der classischen Altertumswissenschaft (dalej: RE), Hlb. 7, Stuttgart 1900, szp. 1596; Idem, Iulia (541), w: RE, Hlb. 19, Stuttgart 1918, szp. 892.

${ }^{6}$ F. Münzer, Cornelius Phagita, w: RE, Hlb. 7..., szp. 1419.

7 Plut., Caes. 1.

${ }^{8}$ Suet., Iul. 1.

9 Vell. 2.41.2.

${ }_{10}$ Zob. H. Peter, Die Quellen Plutarchs in den Biographieen der Römer, Halle 1865, s. 119-129; C. Pelling, The First Biographers: Plutarch and Suetonius, w: A Companion to Julius Caesar..., s. 252266; The Fragments of the Roman Historians, vol. 1, ed. T.J. Cornell, Oxford 2013, s. 382-384. 
Warto zaznaczyć, że o konflikcie między Cezarem a Sullą wspomniał jedynie w biografii Cezara, ani słowem zaś nie odniósł się do niego w żywocie Sulli.

W historiografii wielokrotnie podejmowane były próby wyjaśnienia skomplikowanych relacji Sulli z Cezarem. Niektórzy badacze poświęcili teksty wyłącznie temu wydarzeniu ${ }^{11}$, inni epizod opisywali w licznych biografiach czy to Sulli, czy Cezara $^{12}$. Zainteresowanie historyków tą tematyką nie dziwi, wszak obie postacie należały do najwybitniejszych w dziejach republiki rzymskiej. W moim przekonaniu nie wszystkie problemy związane z konfliktem Sulli i Cezara zostały jednak rozwiązane, a część wymaga świeżego spojrzenia. Dotyczy to zarówno genezy konfliktu, jak i jego istoty. Warto także zastanowić się nad wiarygodnością przekazów źródłowych odnoszących się do wspomnianego wątku i odpowiedzieć na pytanie, na ile był on realny, na ile zaś stał się wytworem późniejszej, cezariańskiej propagandy.

Autorzy antyczni akcentują, że ważną rolę w kształtowaniu się stosunków Sulli z Cezarem odgrywało pochodzenie tego ostatniego. Młody Cezar wywodził się z gens Iulia, jednego z najstarszych rzymskich rodów, a Cezarowie, którzy pojawiają się w źródłach pod koniec III wieku, stanowili jego patrycjuszowską gałąź. Pierwszy odnotowany przez starożytnych Cezar to Sekstus Juliusz, który w 208 roku, podczas zmagań Rzymu z Hannibalem, sprawował urząd pretora. Miał on dwóch synów: Sekstusa (konsula ze 157 roku; jego wnukami byli Lucjusz, konsul z 90 roku, i G. Juliusz Cezar Strabon Wopiskus) i Lucjusza (pretora ze 166 roku). Właśnie ów Lucjusz był ojcem Gajusza Juliusza Cezara (dziadka późniejszego dyktatora). Zachowało się o nim niewiele informacji. Wiadomo, że miał żonę Marcję i troje dzieci: Sekstusa

Por. G.B. Towned, C. Oppius on Julius Caesar, „The American Journal of Philology” 1987, 108, s. $325-342$.

${ }^{11}$ R.T. Ridley, The Dictator's Mistake: Caesar's Escape from Sulla, „Historia” 2000, 49, s. 211229; A.W. Korolenkov [А.В. Короленков], Сулла и Цезарь: противостояние, „Studia Historica” 2013, 13, s. 114-135; O.W. Liubimova, S.E. Taryverdieva [О.В. Любимова, С.Э. Таривердиева], Конфликт Цезаря с Суллой: приключенческий роман, пропаганда или действительность?, „Studia Historica” 2015, 14, s. 66-97. Zob. także: H.H. Howorth, The Rise of Gaius Julius Caesar, with an Account of His Early Friends, Enemies, and Rivals: Part I, „Transactions of the Royal Historical Society” 1907, 1, s. 65-66; L.R. Taylor, Caesar's Early Career, „Classical Philology” 1941, 36, s. $113-116$.

12 J.P.V.D. Balsdon, Julius Caesar and Rome, London 1967, s. 29; J. Carcopino, Jules César, Paris 1968, s. 5-6; A. Keaveney, Sulla. The Last Republican, London-Canberra 1982, s. 154; G. Walter, Cezar, przeł. D. Wilanowska, Warszawa 1983, s. 15-17; A.D. Kahn, The Education of Julius Caesar. A Biography, a Reconstruction, New York 1986, s. 55-59; L. Canfora, Giulio Cesare. Il dittatore democratico, Roma-Bari 1999, s. 3-4; P. Southern, Caesar, [Tempus Publishing] 2001, s. 19-21; Y. Le Bohec, Cezar, przeł. M. Kropiwnicka, Warszawa 2003, s. 18; A. Kamm, Julius Caesar. A Life, London-New York 2006, s. 30-31; A. Goldsworthy, Caesar. Life of a Colossus, New Haven-London 2006, s. 57-59; R.A. Billows, Julius Caesar: The Colossus of Rome, London-New York 2009, s. 54-56; J. Fündling, Sulla, Darmstadt 2010, s. 146. 
Juliusza Cezara (konsula z 91 roku), Gajusza Juliusza Cezara (ojca Cezara) i Julię, która wyszła za mąż za G. Mariusza ${ }^{13}$.

To zatem dziadek Cezara, bo to on zapewne zaaranżował małżeństwo swej córki z tym wybitnym wodzem i politykiem ${ }^{14}$, związał więzami powinowactwa swój ród z rodziną Mariusza. Powiązania te zacieśniały się w kolejnych latach. Ojciec Cezara, o którym wiadomo, że kroczył normalną ścieżką kariery urzędniczej (był trybunem wojskowym, kwestorem, edylem kurulnym i pretorem ${ }^{15}$ ), uczestniczył w akcji osiedleńczej w Afryce, której patronował pogromca Cymbrów i Teutonów. Po zakończeniu sprawowania pod koniec lat 90 . funkcji pretora ojciec Cezara przez co najmniej dwa lata zarządzał prowincją Azją ${ }^{16}$. Nie zachowały się w źródłach dane o jego udziale w wojnie ze sprzymierzeńcami, brak też informacji, po czyjej stronie opowiedział się po zdobyciu Rzymu przez Sullę w 88 roku; prawdopodobnie jednak w pierwszej wojnie domowej wsparł mariańczyków. Najlepszym dowodem na potwierdzenie takiej hipotezy jest fakt, że przeżył, podczas gdy jego kuzynowie ze starszej gałęzi rodu Cezarów - L. Juliusz Cezar i G. Juliusz Cezar Strabon Wopiskus zginęli w czasie masakry mariańskiej w 87 roku $^{17}$. Być może ojca Cezara uratowała jego rodzona siostra Julia, żona Mariusza. Jeśli jednak przeszedł do obozu mariańczyków, to należy przypuszczać, że nie odgrywał w nim znaczącej roli, nie sprawował bowiem ani jednego urzędu w trakcie rządów mariańskich w Rzymie i nie pełnił także wówczas żadnego dowództwa. Wszystko to każe podejrzewać, że jego sympatie mariańskie były umiarkowane. Zmarł nagle, w Pizie, w roku 85 , gdy rano zakładał buty ${ }^{18}$. Dlaczego zawędrował do tego miasta - nie wiadomo. Być może

${ }^{13}$ Szerzej o przodkach Cezara zob. W. Drumann, P. Groebe, Geschichte Roms in seinem Übergange von der republikanischen zur monarchischen Verfassung, Bd. 3, Leipzig 1906, s. 111-125; G.V. Sumner, A Note on Julius Caesar's Great Grandfather, „Classical Philology” 1976, 71, s. $341-344$.

${ }^{14}$ Mariusz, choć osiągnął w republice największe zaszczyty, jako homo novus zajmował w rzymskiej hierarchii społecznej niższe miejsce od członków gens Iulia. Jest więc wątpliwe, aby to od niego wyszła propozycja małżeństwa. W tym kontekście warto przytoczyć jako przykład zaręczyny Tyberiusza Semproniusza Grakchusa z Klaudią. To Appiusz Klaudiusz zaproponował Grakchusowi rękę swej córki, czyniąc tym Grakchusowi ogromny zaszczyt, choć pochodził on przecież z zasłużonej w dziejach republiki gens Sempronia. Por. P. Grimal, Miłość w Rzymie, przeł. J.R. Kaczyński, Warszawa 1990, s. 76-77.

15 Odtworzenie kariery ojca Cezara możliwe jest dzięki odnalezieniu poświęconego mu elogium. Szerzej na ten temat zob. T. Frank, The New Elogium of Julius Caesar's Father, „The American Journal of Philology” 1937, 58, s. 90-93; T.R.S. Broughton, The Elogia of Julius Caesar's Father, „American Journal of Archaeology" 1948, 52, s. 323-330; R.T. Ridley, The Dictator's Mistake..., s. 211, przyp. 4.

16 T.R.S. Broughton, The Magistrates..., s. 22; T. Corey Brennan, The Praetorship in the Roman Republic, vol. 2, Oxford 2000, s. 553, 555.

17 Liv., per. 80; Val. Max. 9.2.2; Flor. 2.9.14; App., BC 1.72.332; M. Lovano, The Age of Cinna: Crucible of Late Republican Rome, Stuttgart 2002, s. 48.

${ }_{18}$ Plin., NH 7.181. 
został tam wysłany w celu rekrutowania wojska na zbliżającą się wojnę z Sullą ${ }^{19}$, nie można także wykluczyć, że po prostu wolał być daleko od Rzymu i rządzącego nim Cynny.

Matką Cezara była Aurelia Kotta i to prawdopodobnie jej koneksje rodzinne uratowały życie młodzieńca po zwycięstwie Sulli. Była córką Rutylii i Lucjusza Aureliusza Kotty, konsula roku 119, pochodziła zatem z bardzo wpływowego w okresie republiki rodu plebejskiego ${ }^{20}$. Ze swoim mężem Cezarem miała dwie córki i syna. Julia Starsza wychodziła za mąż dwukrotnie. Najpierw poślubiła L. Pinariusa, później Kw. Pediusza, a wnukowie z tych związków, o tym samym co dziadek imieniu, zostali uwzględnieni jako spadkobiercy w testamencie Cezara otwartym i ogłoszonym po jego śmierci w 44 roku $^{21}$. Julia Młodsza poślubiła M. Atiusza i była babką cesarza Augusta ${ }^{22}$. Według Tacyta Aurelia była wzorem rzymskiej matki, jak Kornelia dla Grakchów i Atia dla Augusta ${ }^{23}$, według Plutarcha zaś — „bardzo zacną matroną" ${ }^{24}$. Inteligentna, niezależna, piękna, poważana, miała duży wpływ na syna, zwłaszcza że ojca często przy nim nie było. Wiadomo, że Aureliusze Kottowie w okresie wojny domowej wspierali L. Korneliusza Sullę, prawdopodobnie przebywali z nim na Wschodzie i wraz z nim powrócili do Italii, a później, w okresie restauracji sullańskiej, weszli w skład elity władzy ${ }^{25}$.

Trzecią osobą, która odegrała dużą rolę w młodości Cezara, była jego ciotka (siostra ojca) Julia. Około 115 roku została ona żoną G. Mariusza, a w 109 roku urodziła mu syna, Mariusza Młodszego, późniejszego konsula 82 roku, jednego z najbardziej zagorzałych wrogów Sulli ${ }^{26}$. Wydaje się jednak, że matka nie podzielała ówczesnych radykalnych poglądów swego syna ${ }^{27}$. Wiadomo natomiast, że Cezar darzył ciotkę dużym szacunkiem, czego wyraz dał, organizując jej - dużo później,

19 Zob. App., BC 1.77.354.

${ }^{20}$ E. Klebs, Aurelius, w: RE, Bd. 2, Stuttgart 1896, szp. 2431; Idem, Aurelia (248), w: RE, Bd. 2..., szp. 2543; M.E. Deutsch, The Women of Caesar's Family, „The Classical Journal” 1918, 13, s. 502-504.

${ }^{21}$ Suet., Iul. 83.

${ }^{22}$ Ibidem.

23 Tac., De Orat. 28.

${ }^{24}$ Plut., Caes. 9 (przeł. M. Brożek).

${ }^{25}$ W obozie sullańskim znalazło się trzech braci z rodu Aureliuszów Kottów: Marek, Gajusz i Lucjusz. Nie wiadomo nic o ich działalności w latach 80. w Rzymie, co skłania badaczy do stawiania hipotezy, że przebywali wówczas z Sullą na Wschodzie (Cyceron [Brut. 311] zdaje się poświadczać powrót co najmniej jednego z nich u boku Sulli). W latach 70. sprawowali oni najwyższe urzędy w państwie: Gajusz i Marek byli konsulami (kolejno w 75 i 74 roku), a Lucjusz był pretorem (w roku 70). Zob. A. Keaveney, Sulla, Sulpicius and Caesar Strabo, „Latomus” 1979, 38, s. 457, przyp. 17; Idem, Who were the Sullani..., s. 138-139; C.F. Konrad, Cotta off Mellaria and the Identities of Fufidius, „Classical Philology” 1989, 84, s. 120-122.

${ }_{26}$ F. Münzer, C. Marius (15), w: RE, Hlb. 28, Stuttgart 1930, szp. 1812.

${ }^{27}$ Sall., Hist. $1.30 \mathrm{McG}=1.35 \mathrm{M}$ (Adnot. super Lucanum: „Hic est Marius, qui invita matre Iulia adeptus est consulatum, de quo Sallustius meminit"). 
bo w początkach lat 60. - spektakularny pogrzeb, podczas którego wygłosił znaną powszechnie mowę ${ }^{28}$.

W okresie pierwszej wojny domowej młody Cezar pozostawał w Rzymie. Rodzice w tym burzliwym okresie musieli zadbać o jego bezpieczeństwo. Zaczęli od wyboru przyszłej żony. Pierwszą narzeczoną Cezara została Kosucja (Cossutia), bogata ekwitka, z którą zaręczyny datować należy na okres przed lipcem 85 roku ${ }^{29}$. Interesująca jest kwestia, dlaczego ojciec Cezara - bo to zapewne on odpowiedzialny był za zaaranżowanie małżeństwa - wybrał swemu synowi akurat taką kandydatkę na żonę. Kosucjusze (Cossutii) nie mieli wśród przodków żadnego konsula, znani są jedynie dwaj triumwirowie monetarni z czasów późniejszych (połowa lat 70. i 44 rok $)^{30}$. Z politycznego punktu widzenia był to więc swoisty mezalians. Znaczenie miało zapewne bogactwo Kosucjuszy. $Z$ drugiej strony wybór przyszłej małżonki $\mathrm{z}$ rodu o małym znaczeniu politycznym potwierdzałby zachowawczą postawę ojca Cezara wobec umizgów mariańczyków. Kosucja nie mogła nikogo politycznie drażnić. Jednocześnie prawdopodobnie pochodziła z rodu o sympatiach mariańskich, a małżeństwo z nią kontynuowałoby tradycję Juliuszów, którzy od kilku pokoleń wiązali się z plebejuszkami ${ }^{31}$.

Narzeczeństwo z Kosucją zostało zerwane najpewniej niedługo po śmierci ojca Cezara $^{32}$. To wówczas - jak się wydaje — doszło do silniejszego zbliżenia się młodego Cezara do obozu mariańskiego. Wynikało to $\mathrm{z}$ dwóch powiązanych ze sobą spraw: kapłaństwa Jowisza, które młody Cezar miał sprawować, oraz z małżeństwa Cezara z Kornelią, córką Cynny.

Jako flamen Dialis Cezar miał stanąć na czele kolegium piętnastu kapłanów, a także przewodzić kultowi głównego bóstwa państwowego. Data nominacji Cezara jest trudna do określenia; wskazówką jest okoliczność, że L. Korneliusz Merula, ostatni z kapłanów Jowisza, popełnił samobójstwo w 87 roku $^{33}$. Większość badaczy uważa, że wyznaczenie Cezara miało miejsce w 84 roku, ale nominacja mogła mieć miejsce wcześniej, już pod koniec 87 lub na początku 86 roku, jeszcze za życia G. Mariusza ${ }^{34}$. Ważniejsze jest, kto i dlaczego zdecydował o powierzeniu tej funkcji Cezarowi i jak do tych planów on sam był nastawiony. Nic nie wiadomo o jego niechęci wobec propozycji objęcia kapłaństwa Jowisza, pewne jest natomiast, że w przeszłości takie protesty kandydatów się zdarzały. W 209 roku pontifex maximus

${ }^{28}$ Suet., Iul. 9; W.J. Tatum, Always I am Caesar, [Blackwell Publishing] 2008, s. 100.

${ }^{29}$ Suet., Iul. 1.

${ }^{30}$ M. Crawford, Roman Republican Coinage, vol. 1, Oxford 1974, s. 408, 487, 490-491, 493.

${ }^{31}$ R. Syme, Roman Revolution, Oxford 1939, s. 25.

32 Suet., Iul. 1.

${ }_{33}$ App., $B C$ 1.74.342.

${ }^{34}$ Wellejusz Paterkulus (2.43.1) utrzymuje, że Cezar został flamenem w wieku chłopięcym, za sprawą Mariusza i Cynny („cum paene puer a Mario Cinnaque flamen dialis creatus”). Zob. J. Linderski, Roman Questions II, Stuttgart 2007, s. 637. 
P. Licyniusz zmusił G. Waleriusza Flakkusa, wbrew jego woli, do objęcia obowiązków kapłana kultu Jowisza ${ }^{35}$. Niepopularność tej funkcji wynikała prawdopodobnie z restrykcji, jakimi flamen Dialis był ograniczony ${ }^{36}$, choć w okresie późnej republiki nie były one już tak ściśle przestrzegane (dość powiedzieć, że Merula pełnił konsulat, a matka Cezara nie była patrycjuszką, lecz pochodziła z rodu plebejskiego, podczas gdy oboje rodzice kapłana Jowisza powinni być patrycjuszami). Cezar zakazów religijnych nie traktował poważnie - widać to co prawda dopiero w późniejszym etapie jego życia, ale można np. argumentować, że jako pontifex maximus (od 63 roku) większość czasu był w Rzymie nieobecny. Dla niektórych badaczy wyznaczenie Cezara na urząd kapłana Jowisza było dowodem na jego kolaborowanie z obozem mariańskim ${ }^{37}$, dla innych była to ucieczka Cezara przed niepewną polityczną przyszłością, zwłaszcza przed służbą wojskową ${ }^{38}$. Należy także podkreślić, że Cezar nigdy nie został inaugurowany na stanowisko kapłana Jowisza. Powołanie odbywało się bowiem w trzech etapach: nominatio, capito i inauguratio ${ }^{39}$. Cezar przeszedł dwa pierwsze, na trzeci nigdy nie zgodził się pontifex maximus Kw. Mucjusz Scewola, zamordowany na polecenie Mariusza Młodszego w $82 \mathrm{roku}^{40}$.

Sojusz z Cynną wiązał się z jednej strony z nominacją młodego Cezara na kapłana Jowisza, z drugiej zaś został przypieczętowany małżeństwem z córką Cynny, Kornelią ${ }^{41}$. Flamen Dialis musiał mieć żonę z rodu patrycjuszowskiego, a małżeństwo należało zawrzeć według starożytnej ceremonii confarreatio ${ }^{42}$. Kornelia spełniała ten wymóg. Cezar jako flamen Dialis awansował na wyższą pozycję w państwie, był zatem atrakcyjniejszą partią dla córki czterokrotnego konsula. Z tej perspektywy powierzenie kapłaństwa Jowisza Cezarowi było korzystne zarówno dla niego, jak i dla Cynny. Możliwe także, że Cynna po śmierci ojca Cezara nie dowierzał Aurelii

35 Liv. 28.8.4.

36 Kapłan Jowisza nie mógł: składać przysięgi, spędzać więcej niż trzech kolejnych nocy poza granicami miasta, przebywać z armią na wojnie, patrzeć na zwłoki, a także na kogoś pracującego w dzień świąteczny. Nie wolno mu było dosiadać wierzchowca, nosić odzieży wiązanej węzłami, a nawet posiadać takiej odzieży w domu. Na jego stole zawsze musiała znajdować się żywność; golić i strzyc mógł go niewolnik przy użyciu brązowego noża, a obcięte resztki należało grzebać w sekretnym miejscu. Nosił specjalną futrzaną czapkę. Flamen nie mógł również dotykać bluszczu ani przechodzić pod pędami winorośli, nie mógł dotykać kozy ani psa. Zob. Gell. 10.15; W. Pötscher, Flamen Dialis, „Mnemosyne” 1968, 21, s. 215-239; A. Goldsworthy, Caesar..., s. 50.

37 E. Badian, Foreign Clientelae, Oxford 1958, s. 242.

38 G. Walter, Cezar..., s. 13.

39 R.T. Ridley, The Dictator's Mistake..., s. 215.

${ }^{40}$ L.R. Taylor, Caesar's Early Career..., s. 115-116; M. Leone, Il problema del flaminato di Cesare, w: Studi di storia antica offerti a Eugenio Manni, Rome 1973, s. 193-212; B. Liou Gille, César, "flamen Dialis destinatus”, "Revue des Études Anciennes” 1999, 101, s. 452-453. Por. T.R.S. Broughton, The Magistrates..., s. 73.

${ }^{41}$ Suet., Iul. 1; Plut., Caes. 1. Por. Vell. 2.41.

${ }^{42}$ J. Scheid, Kapłan, w: Człowiek Rzymu, red. A. Giardina, przeł. P. Bravo, Warszawa 1997, s. 96. 
i obawiał się, że będzie ona próbowała rozluźnić relacje gens Iulia z obozem władzy. Planując więc małżeństwo Cezara z Kornelią, chciał jednocześnie ściśle związać swój ród z gens Iulia.

Nie można wykluczać jeszcze jednej ewentualności. Zakładając, że do małżeństwa doszło po śmierci ojca Cezara, wydaje się prawdopodobne, że za aranżacją związku stała jego matka Aurelia. Doprowadzając do sojuszu z Cynną i powierzenia kapłaństwa Jowisza swemu synowi, starała się być może zapewnić mu bezpieczeństwo. Cezar jako kapłan Jowisza nie mógł bowiem brać czynnego udziału w działaniach wojennych. $Z$ drugiej strony Cynnie z pewnością zależało na osłabieniu obozu sullańskiego, zaś sojusz z Aurelią dawał nadzieję na pozyskanie do jego obozu Aureliuszy, którzy — jak wspomniałem — przejawiali sympatie prosullańskie ${ }^{43}$.

Nie wiadomo, czy w zawarciu sojuszu z Cynną uczestniczyła Julia, ciotka Cezara, ale jest to wielce prawdopodobne. Jako wdowa po Mariuszu cieszyła się w stronnictwie mariańskim dużym poważaniem i mogła pośredniczyć w rozmowach między Aurelią a Cynną.

Młody Cezar nie wziął udziału w działaniach wojennych prowadzonych w latach 83-82 (czyli w tzw. wojnie sullańskiej). Po zwycięstwie Sulli nie dosięgła go także fala represji. Plutarch podaje, że „wśród przeprowadzonych masowych mordów i wielkiej ilości innych zajęć Sulla Cezara przeoczył" ${ }^{44}$. Wellejusz Paterkulus dodaje, że z chwilą zwycięstwa Sulli, który unieważnił wszystkie zarządzenia swych przeciwników, Cezar utracił godność kapłana Jowisza ${ }^{45}$. Dyktator nalegał jedynie, aby Cezar rozwiódł się z Kornelią. Według wszystkich autorów źródeł opisujących relacje między Cezarem a Sullą to właśnie odmowa w tej sprawie legła u podstaw konfliktu między nimi.

Dlaczego dyktatorowi tak bardzo zależało na rozwodzie młodzieńca z Kornelią? I czy rzeczywiście konflikt Sulli z Cezarem przybrał rozmiary prezentowane przez autorów antycznych i jeszcze bardziej — jak się wydaje — eksponowane przez współczesnych badaczy?

Motywy Sulli, który dążył do rozwodu Cezara z Kornelią, wydają się stosunkowo jasne - Kornelia była córką Cynny, jego wielkiego wroga. Jeśli więc Cezar chciałby uniknąć prześladowań ze strony dyktatora i ewentualnie związać się z obozem władzy, winien odprawić żonę. Tak zrobił np. M. Pupiusz Pizon Frugi, który, chcąc przypodobać się Sulli, rozwiódł się z Annią, wdową po Cynnie ${ }^{46}$. Wiadomo, że Sulla ingerował w małżeństwa swoich sojuszników - kazał choćby rozwieść się Pompejuszowi z Antystią i ożenić z Emiliąa ${ }^{47}$ W przypadku Cezara sytuacja

\footnotetext{
${ }^{43}$ M. Grant, Julius Caesar, London 1969, s. 23 n.; R.T. Ridley, The Dictator's Mistake..., s. 218.

${ }^{44}$ Plut., Caes. 1 (przeł. M. Brożek).

45 Vell. 2.43: „[...] cum paene puer a Mario Cinnaque flamen dialis creatus victoria Sullae, qui omnia ab iis acta fecerat irrita, amisisset id sacerdotium".

${ }^{46}$ Vell. 2.41.

${ }^{47}$ Plut., Pomp. 9.
} 
była o tyle inna, że nic nie wiadomo, aby dyktator wyszukał mu nową kandydatkę na żonę. Pozwala to przypuszczać, że chodziło mu wyłącznie o zerwanie więzów Cezara z mariańczykami.

Oczywiście nie można wykluczyć, że za niewygórowanym — jak się wydaje żądaniem Sulli kryły się jakieś inne plany wobec Cezara. Część uczonych twierdzi, że dyktator uważał siebie za przywódcę arystokracji, a nawet że polityka Sulli zmierzała do ukształtowania nowej arystokracji, którą chciał zbudować na bazie młodych, zdolnych przedstawicieli możnych rodów ${ }^{48}$. Cezar idealnie pasowałby do realizacji takich planów. Był młodym patrycjuszem, o doskonałym pochodzeniu i koneksjach rodzinnych. Miał też czystą kartę w wojnie domowej, w której nie wystąpił przeciwko Sulli. Dlatego też dyktator czynił starania, aby się do niego zbliżyć. Jedyne, czego od niego żądał, to rozwodu z córką znienawidzonego Cynny.

Rozumowanie takie ma jednak słabe podstawy, opiera się bowiem w głównej mierze na wiedzy o późniejszej pozycji i znaczeniu Cezara. Tymczasem w 82 roku był on zaledwie jednym $\mathrm{z}$ wielu młodzieńców, wywodzących się $\mathrm{z}$ arystokratycznego rodu, co prawda o dużym znaczeniu historycznym, ale wtedy zubożałego. Nic więc dziwnego, że Sulla u progu swej dyktatury Cezara „przeoczył”. Zwrócił na niego uwagę dopiero po pewnym czasie, gdy młodzieniec odmówił rozwodu z Kornelią. Najwyraźniej nie wywołało to jeszcze wściekłości dyktatora, który skonfiskował jedynie posag Kornelii, pozostawiając samego Cezara w spokoju. Dopiero gdy ten ośmielił się "publicznie wystąpić ze swą kandydaturą do urzędu kapłańskiego"49, Sulla - najwyraźniej poruszony tą niesubordynacją - zaczął rozważać ukaranie Cezara śmiercią, czym sprowokował go do ucieczki z Rzymu. Nie wiadomo, o jaki konkretnie urząd kapłański ubiegał się Cezar. Większość badaczy w ogóle pomija wzmiankę Plutarcha na ten temat, inni widzą w niej zniekształconą wersję walki Cezara o zachowanie flaminatu ${ }^{50}$. Stanowisko to nie było jednak obsadzane na drodze wyborów, możliwe zatem, że Cezarowi chodziło o zdobycie jakiegoś innego urzędu kapłańskiego, być może o dostęp do kolegium pontyfików, do którego został wybrany w drugiej połowie lat $70 .{ }^{51}$ Jakkolwiek było, zachowanie Cezara zirytowało Sullę, który doprowadził do zablokowania jego wyboru. Na skutek tego wydarzenia relacje między Sullą i Cezarem tak bardzo się pogorszyły, że młodzieniec uznał za stosowne zejść $\mathrm{z}$ oczu dyktatorowi i udał się do posiadłości matki w kraju Sabinów ${ }^{52}$.

Swetoniusz przedstawia sprawę nieco inaczej. Podaje bowiem, że gdy Cezar nie zgodził się na rozwód z Kornelią, Sulla „za karę pozbawił go urzędu kapłańskiego,

\footnotetext{
${ }^{48}$ G. Baker, Sulla the Fortunate, London 1927, s. 269; R.T. Ridley, The Dictator's Mistake..., s. 219.

${ }^{49}$ Plut., Iul. 1.

${ }^{50}$ L.R. Taylor, Caesar's Early Career..., s. 116.

${ }^{51}$ T.R.S. Broughton, The Magistrates..., s. 113.

52 Vell. 2.41; Plut., Iul. 1.
} 
posagu żony i rodowych dziedzicznych majętności oraz uznał za wroga" ${ }^{33}$. Na podstawie tej informacji uczeni formułują wniosek, że konsekwencją odmowy Cezara było umieszczenie jego nazwiska na liście proskrypcyjnej i konieczność ucieczki z Rzymu ${ }^{54}$.

Powody odmowy Cezara wobec żądań Sulli interpretowane były w różny sposób. Część historyków uważa, że sprzeciwił się on dyktatorowi, ponieważ pozostawał w relacjach uczuciowych ze swą młodą żoną, która w dodatku była matką Julii, jego jedynego dziecka ${ }^{55}$. Jest jednak niemal pewne, że Julia urodziła się dopiero w latach 70., już po śmierci Sulli ${ }^{56}$. W dodatku małżeństwo traktowano w ówczesnym Rzymie jako pragmatyczne sfinalizowanie targu politycznego, a nie romantyczny związek dwojga ludzi ${ }^{57}$. Inni badacze wskazywali na charakterystyczne dla arystokraty rzymskiego dumę i poczucie własnej godności. Cezar, członek patrycjuszowskiego rodu z olbrzymimi tradycjami, nie chciał podporządkować się rozkazowi rozwiązania swego małżeństwa, nawet jeśli padł on ze strony zwycięskiego w wojnie domowej Sulli58. Słabość tej hipotezy — oprócz łatwych do przewidzenia konsekwencji odmowy - stanowić może brak reakcji Cezara na jego wcześniejsze związki: narzeczeństwo z Kosucją czy małżeństwo z Kornelią. Obydwa były aranżowane przez bliskich Cezara i w źródłach nie ma śladów protestów Cezara wobec tych planów małżeńskich.

Szukając motywów sprzeciwu wobec woli Sulli, sformułowano teorię, że Cezar już od lat młodzieńczych charakteryzował się dużą samodzielnością polityczną i chciał stworzyć własną factio, a weto wobec żądania dyktatora miałoby go odróżniać od członków obozu sullańskiego, pokornie wypełniających polecenia dyktatora $^{59}$. Takiego poglądu nie potwierdza jednak działalność Cezara w latach 70., a jego młody wiek czyni takie założenie wręcz niemożliwym. Poszukiwano wobec tego argumentów bardziej racjonalnych. Chodzi w tym przypadku o poszanowanie zwyczajów rzymskich. Wspomniałem już, że jako kandydat na kapłana Jowisza musiał zawrzeć z Kornelią małżeństwo według starożytnej ceremonii confarreatio. W takich okolicznościach wzięcie rozwodu uważano za wielką niestosowność. Dowodzono więc, że była to główna przyczyna odmowy Cezara ${ }^{60}$.

${ }^{53}$ Suet., Iul. 1 (przeł. J. Niemirska-Pliszczyńska).

${ }^{54}$ A. Keaveney, Sulla..., s. 154.

${ }^{55}$ G. Walter, Cezar..., s. 16. Zob. R.T. Ridley, The Dictator's Mistake..., s. 220.

${ }^{56}$ R.T. Ridley, The Dictator's Mistake..., s. 220; P. Southern, Caesar..., s. 18; A. Goldsworthy, Caesar..., s. 82; A. Kamm, Julius Caesar..., s. 30. We wcześniejszej literaturze przeważa pogląd, że Julia urodziła się w 83 roku; nie jest on już dzisiaj akceptowany. Por. F. Münzer, Iulia (547), w: RE, Hlb. 19, Stuttgart 1918, szp. 894; M.E. Deutsch, The Women of Caesar's Family..., s. 511.

57 P. Grimal, Miłość w Rzymie..., s. 77.

${ }_{58}$ A. Goldsworthy, Caesar..., s. 58.

59 Por. E. Gruen, The Last Generation of the Roman Republic, Berkeley-Los Angeles-London 1974, s. 15.

${ }^{60}$ A. Kamm, Julius Caesar..., s. 30-31; J. Linderski, Roman Questions II..., s. 636-637. 
Skutek niesubordynacji Cezara pozostawał ten sam - musiał on opuścić Rzym i zniknąć z oczu dyktatorowi. Przyczyny tego kroku ujmowane są jednak w przekazach antycznych w sposób zgoła inny. Dla Swetoniusza wynikała ona z jednorazowej samowoli młodzieńca, który nie wykonał rozkazu dyktatora i nie rozwiódł się z żoną. Według Plutarcha zaś konflikt narastał stopniowo, a ze słów biografa można wysnuć wniosek, że Cezar próbował budować niezależną pozycję względem Sulli, czym wywołał jego (lub jego najbliższych współpracowników) niezadowolenie i w konsekwencji musiał wyjechać ze stolicy.

Otwarta pozostaje kwestia, czy Sulla proskrybował Cezara. W moim przekonaniu to mało prawdopodobne. Przede wszystkim żaden autor antyczny tego wyraźnie nie potwierdza i już na tej podstawie sąd, że nazwisko Cezara znalazło się na listach proskrypcyjnych, ma słabe uzasadnienie ${ }^{61}$. Dodajmy do tego łagodne postępowanie Sulli wobec innych patrycjuszy, a także fakt, że do konfliktu między Cezarem a Sullą nie doszło bezpośrednio po zwycięstwie Sulli w wojnie domowej, ale dopiero po jakimś czasie, prawdopodobnie już po 1 czerwca 81 roku, czyli po oficjalnym zakończeniu proskrypcji ${ }^{62}$. Okoliczności, że Cezar był zięciem Cynny, nie można w moim przekonaniu uznać za wystarczającą, aby jego nazwisko znalazło się na listach proskrypcyjnych. Był wówczas politycznie zbyt mało znaczącą postacią, a co nie mniej ważne - nie należał do ludzi zamożnych.

Z informacji źródłowych wynika, że w otoczeniu dyktatora znajdowali się ludzie, którzy nastawiali go wrogo wobec młodego Cezara ${ }^{63}$. Możliwe, że to między innymi na skutek ich zabiegów Cezar musiał uciekać z Rzymu. Autorzy źródeł nie podają ich nazwisk, więc można snuć jedynie na ten temat domysły. Niewykluczone, że w okresie dyktatury źle wobec Cezara nastawiony był konsul 81 roku, Gn. Korneliusz Dolabella ${ }^{64}$. W 77 roku, gdy po śmierci Sulli Cezar powrócił do Rzymu, właśnie Dolabellę oskarżył przed sądem o nadużycia, jakich dopuścił się on podczas namiestnictwa w Macedonii ${ }^{65}$. Można tylko spekulować, czy atak Cezara na

${ }^{61} \mathrm{O}$ tym, że Cezar nie był proskrybowany, przekonani są np. Fündling (J. Fündling, Sulla..., s. 146) oraz Liubimova i Taryverdieva (O.W. Liubimova, S.E. Taryverdieva [O.В. Любимова, С.Э. Таривердиева], Конфликт Цезаря с Суллой..., s. 96). Brak również nazwiska Cezara wśród proskrybowanych skatalogowanych przez Hinarda (F. Hinard, Les proscriptions..., s. 359-360).

${ }^{62}$ Ridley (R.T. Ridley, The Dictator's Mistake..., s. 222) bez podawania argumentów uznaje, że Cezar był proskrybowany i na tej podstawie konflikt z Sullą datuje na okres między końcem 82 a lipcem 81 roku. Tymczasem z przekazu Plutarcha (Caes. 1) i pośrednio Wellejusza Paterkulusa (2.41) wynika, że konflikt nastąpił później. O proskrybowaniu Cezara przekonani są także np.: Drumann, Groebe (W. Drumann, P. Groebe, Geschichte Roms..., s. 127), Keaveney (A. Keaveney, Sulla..., s. 154), Badian (E. Badian, From the Iulii to Caesar..., s. 17). Zob. Cic., Rosc. Am. 128 o dacie kończącej proskrypcje.

${ }^{63}$ Vell. 2.41.2.

${ }^{64}$ Por. E. Gruen, The Dolabellae and Sulla, „The American Journal of Philology” 1966, 87, s. 387.

${ }^{65}$ Cic., Brut. 307; Vell. 2.43.3; Val. Max. 8.9.3; Ascon. 26; 74C; Plut., Caes. 4.1; Tac., Dial. 34; Suet., Iul. 4.1; Vir. Ill. 78.2. Zob. M.C. Alexander, Trials in the Late Roman Republic, Toronto 1990, s. 71. 
Dolabellę wynikał z typowej dla młodych Rzymian praktyki zbierania doświadczenia w sądach i chęci uzyskania w ten sposób rozgłosu czy jednak z osobistej urazy, jaką poczuł do niego w okresie jego konsulatu w 81 roku.

Młody Cezar w obozie sullańskim miał także wiernych przyjaciół. To oni, najpewniej dzięki prośbom Aurelii, postarali się ułagodzić Sullę. Wśród nich był na przykład Mamerkus Emiliusz Lepidus Liwianus, konsul 77 roku, niewątpliwie zdeklarowany sullańczyk, który wziął później udział w tłumieniu powstania swego kuzyna Lepidusa. Liwianus był Liwiuszem adoptowanym przez Emiliuszy, a ponieważ Aurelia powiązana była z Rutyliuszami, z którymi z kolei powiązani byli Liwiusze, dowodzi to pokrewieństwa z samym Cezarem, choć - trzeba przyznać - dość odległego ${ }^{66}$. Innym krewnym wspierającym Cezara był G. Aureliusz Kotta, najstarszy z kuzynów Aurelii, który wraz z Sullą powrócił do Italii w $83 \mathrm{roku}^{67}$. Zarówno Liwianus, jak i Aureliusz Kotta byli pontyfikami i dopuścili Cezara do tego kolegium w 74 lub w 73 roku, co wskazuje, że ich współpraca nie ograniczyła się do jednego epizodu, lecz trwała przez całą dekadę rządów sullańczyków w republice. Obok nich o ułaskawienie Cezara zabiegały także dwie nieznane $\mathrm{z}$ imienia westalki ${ }^{68}$. Czy robiły to ze względu na kapłańską przeszłość młodego Cezara, czy też na prośbę jego kuzyna, kapłana Kwiryna, Sekstusa Juliusza Cezara (syna konsula $91 \mathrm{roku}$ ), nie sposób ostatecznie rozstrzygnąc $c^{69}$. Nie zachowały się szczegóły dotyczące tematyki rozmów z Sullą, nie chodziło jednak chyba o ocalenie życia Cezara, a raczej o jego przywrócenie do łask, a nade wszystko zwrot skonfiskowanego Kornelii majątku ${ }^{70}$.

Po ucieczce Cezara z Rzymu - czy to przed gniewem dyktatora, czy to, co bardziej prawdopodobne, na skutek knowań przeciwników z otoczenia Sulli ukrywał się on w dobrach matki w kraju Sabinów. Autorzy źródeł przekazują niemal awanturniczą opowieść o tym, jak chory na malarię młodzieniec, w obawie przed ścigającymi go oprawcami, co noc zmieniał miejsce pobytu i jak wreszcie został schwytany przez oddział dowodzony przez niejakiego Korneliusza Fagitę. To owemu Fagicie Cezar miał wręczyć łapówkę w wysokości dwóch talentów i w ten sposób ocalić życie ${ }^{71}$. Historia przekazana przez autorów źródeł jest tak nieprawdopodobna i pełna sprzeczności, że trudno ją zaakceptować. Bardziej zasadne wydaje się przypuszczenie A.W. Korolenkova, że Fagita był wyzwoleńcem i wysłannikiem Sulli, który dobrze wiedział, gdzie szukać Cezara, i został wyekspediowany do niego, aby wręczyć mu ułaskawienie, propozycję kompromisu lub dalsze rozkazy od dyk-

${ }^{66}$ A. Keaveney, Who were the Sullani?..., s. 138; R.T. Ridley, The Dictator's Mistake..., s. 223.

${ }^{67}$ A. Keaveney, Sulla..., s. 557, przyp. 17.

68 Suet., Iul. 1; J. Carcopino, Jules César..., s. 6.

${ }^{69}$ Zob. G. Walter, Cezar..., s. 17.

${ }^{70}$ A.W. Korolenkov [А.В. Короленков], Сулла и Цезарь..., s. 130.

${ }^{71}$ Plut., Caes. 1; Suet., Iul. 74. Zob. T. Rice Holmes, The Roman Republic and the Founder of the Empire, vol. 1, Oxford 1923, s. 222; E. Badian, From the Iulii to Caesar..., s. 17. 
tatora $^{72}$. Cezar nie powrócił bowiem do Rzymu, lecz udał się do Azji i jako contubernalis wszedł w skład sztabu tamtejszego namiestnika M. Minucjusza Termusa, gdzie zdobywał pierwsze szlify wojenne ${ }^{73}$.

Niektórzy badacze próbowali sugerować, że Cezar odrzucił wyciągniętą do niego rękę Sulli i nie przyjął oferowanego mu ułaskawienia. Dowodzili, że gdyby było inaczej, Cezar powróciłby do Rzymu, a tymczasem wybrał podróż na Wschód ${ }^{74}$. Należy jednak podkreślić, że zarówno Minucjusz Termus, jak i Serwiliusz Watia, do którego Termus wysłał Cezara z misją, byli sullańczykami ${ }^{75}$. Można przypuszczać, że odgrywali w obozie sullańskim ważną rolę, skoro sprawowali w okresie dyktatury najwyższe urzędy w państwie ${ }^{76}$. Gdyby Cezar pozostawał w konflikcie z Sullą lub gdyby był wrogiem systemu sullańskiego, wówczas zapewne ruszyłby na Zachód, tak jak jego szwagier, proskrybowany syn Cynny, który zasilił szeregi rewolty sertoriańskiej. Służba na Wschodzie u boku wspomnianych sullańczyków, tam, gdzie niegdyś namiestnictwo sprawował ojciec Cezara, może w moim przekonaniu stanowić przesłankę potwierdzającą, że Sulla zawarł z Cezarem kompromis.

Istnieją poszlaki pozwalające przypuszczać, że przez następną dekadę Cezar stawał się coraz ściślej powiązany z sullańczykami dzierżącymi w republice władzę. Służył w sztabie Marka Antoniusza w trakcie jego wyprawy przeciwko piratom, został wybrany do kolegium kapłańskiego, a także pod koniec lat 70. zwyciężył w wyborach na trybuna wojskowego ${ }^{77}$. Oczywiście nie były to osiągnięcia imponujące. Należy jednak pamiętać, że w latach 70 . Cezar był wciąż człowiekiem młodym, stojącym dopiero u progu kariery politycznej i wojskowej. I choć przemawiało za nim patrycjuszowskie pochodzenie, nie mógł jeszcze odgrywać w państwie znaczącej roli politycznej.

Sulla, jak już nadmieniłem, wybaczył Cezarowi, wypowiadając profetyczne słowa: „w tym Cezarze drzemie wielu Mariuszów”78. Być może to w tym krótkim zdaniu, z lubością przytaczanym przez współczesnych badaczy ${ }^{79}$, kryje się rozwią-

${ }^{72}$ Możliwe, że dyktator zgodził się przywrócić majątek Kornelii i cofnął żądanie rozwodu. Zob. A.W. Korolenkov [А.В. Короленков], Сулла и Цезарь..., s. 130-131; O.W. Liubimova, S.E. Taryverdieva [О.В. Любимова, С.Э. Таривердиева], Конфликт Цезаря с Суллой..., s. 93. Kornelia pozostała żoną Cezara do swej śmierci, czyli do około 69 roku. Zob. A. Goldsworthy, Caesar..., s. 98. Por. Plut., Caes. 5.7; Suet., Iul. 6.2; M.E. Deutsch, The Women of Caesar's Family..., s. 506.

${ }^{73}$ Suet., Iul. 2, por. 22.2. Zob. Cass. Dio 43.20.3; Vir. Ill. 78.1; L. Canfora, Giulio Cesare..., s. $4-5$.

${ }^{74}$ Por. R.T. Ridley, The Dictator's Mistake..., s. 227.

${ }^{75}$ A. Keaveney, Who were the Sullani?..., s. 128 (Serwiliusz Watia), 140 (Minucjusz Termus).

${ }^{76}$ Minucjusz Termus w 81 roku sprawował preturę, a Serwiliusz Watia był konsulem roku 79. Zob. T.R.S. Broughton, The Magistrates..., s. 76, 82.

77 Ibidem, s. 113, 125.

${ }^{78}$ Suet., Iul. 1. Zob. Plut., Caes. 1.

79 T. Rice Holmes, The Roman Republic..., s. 222; G. Walter, Cezar..., s. 17; C. Meier, Caesar, München 1986, s. 130; Y. Le Bohec, Cezar..., s. 18; L. Canfora, Giulio Cesare..., s. 4; P. Southern, 
zanie zagadkowych okoliczności konfliktu Sulli z Cezarem. Oczywiście można być niemal pewnym, że zacytowane słowa nigdy nie zostały przez Sullę wypowiedziane. Stanowią kreację historyków, którzy wiedzieli, jak potoczyły się losy Cezara i z kim związał w przyszłości swe polityczne sympatie. Jednocześnie jednak można podejrzewać, że pamięć o nieporozumieniach $\mathrm{z}$ Sullą - w przeciwieństwie do pamięci o zawartym z nim kompromisie - była Cezarowi na rękę, konflikt z dyktatorem podkreślał bowiem w pewien sposób odrębność młodzieńca od sullańczyków, co mogło ułatwić jego późniejsze zbliżenie z popularami. Spór Cezara z Sullą być może został więc przez tego pierwszego niejako wykreowany, a jego znaczenie w rzeczywistości było o wiele mniejsze, niż się dzisiaj na ogół uważa ${ }^{80}$.

Jedno jest pewne - niesnaski Cezara z Sullą toczyły się na marginesie głównych wydarzeń politycznych okresu dyktatury, a pamięć o nich zachowała się dzięki roli, jaką Cezar odegrał w dalszych dziejach republiki. Stanowi to zaledwie przyczynek do biografii Cezara, który w okresie dyktatury Sulli i restauracji sullańskiej, mimo początkowych nieporozumień z dyktatorem, budował swoją karierę, współpracując z obozem władzy. Pokazuje także sposób postępowania Sulli z przedstawicielami elity arystokratycznej, która nie zawsze działała zgodnie z oczekiwaniami dyktatora. Z punktu widzenia Sulli spór z Cezarem nie miał prawdopodobnie żadnego znaczenia i nawet jeśli młodzieniec wykazywał już wówczas cechy, które pozwoliły mu w przyszłości wybić się ponad wszystkich, to Sulli nigdy nie było dane się o tym przekonać.

\section{Bibliografia}

Alexander M.C., Trials in the Late Roman Republic, Toronto 1990.

Badian E., Foreign Clientelae, Oxford 1958.

Badian E., From the Iulii to Caesar, w: A Companion to Julius Caesar, ed. M. Griffin, [Blackwell Publishing] 2009.

Baker G., Sulla the Fortunate, London 1927.

Balsdon J.P.V.D., Julius Caesar and Rome, London 1967.

Billows R.A., Julius Caesar: The Colossus of Rome, London-New York 2009.

Broughton T.R.S., The Elogia of Julius Caesar's Father, „American Journal of Archaeology” 1948, 52, s. $323-330$.

Caesar..., s. 20; A. Kamm, Julius Caesar..., s. 31; E. Badian, From the Iulii to Caesar..., s. 17; R.A. Billows, Julius Caesar..., s. 54.

${ }^{80}$ Zob. np. rozważania Taylor (L.R. Taylor, Caesar and the Roman Nobility, „Transactions and Proceedings of the American Philological Association" 1942, 73, s. 5) i Southern (P. Southern, Caesar..., s. 20-21) o kompromisie Cezara z Sullą i jego niewielkim znaczeniu na scenie politycznej u progu lat 70., a także argumentację przedstawioną przez Korolenkova (A.W. Korolenkov [А.В. Короленков], Сулла и Цезарь..., s. 132-133). 
Broughton T.R.S., The Magistrates of the Roman Republic, vol. 2, New York 1952.

Canfora L., Giulio Cesare. Il dittatore democratico, Roma-Bari 1999.

Canfora L., Proscrizioni e dissesto sociale nella repubblica Romana, „Klio” 1980, 62, s. 425-438.

Carcopino J., Jules César, Paris 1968.

Corey Brennan T., The Praetorship in the Roman Republic, vol. 2, Oxford 2000.

Crawford M., Roman Republican Coinage, vol. 1, Oxford 1974.

Deutsch M.E., The Women of Caesar's Family, „The Classical Journal” 1918, 13, s. 502-514.

Drumann W., Groebe P., Geschichte Roms in seinem Übergange von der republikanischen zur monarchischen Verfassung, Bd. 3, Leipzig 1906.

Frank T., The New Elogium of Julius Caesar's Father, „The American Journal of Philology” 1937, 58, s. 90-93.

The Fragments of the Roman Historians, ed. T.J. Cornell, vol. 1, Oxford 2013.

Fündling J., Sulla, Darmstadt 2010.

Goldsworthy A., Caesar. Life of a Colossus, New Haven-London 2006.

Grant M., Julius Caesar, London 1969.

Grimal P., Miłość w Rzymie, przeł. J.R. Kaczyński, Warszawa 1990.

Gruen E., The Dolabellae and Sulla, „The American Journal of Philology” 1966, 87, s. 385-399.

Gruen E., The Last Generation of the Roman Republic, Berkeley-Los Angeles-London 1974.

Henderson J., Sulla's List: The First Proscription, „Parallax” 2003, 9, s. 39-47.

Hinard F., Les proscriptions de la Rome républicaine, Paris-Roma 1985.

Howorth H.H., The Rise of Gaius Julius Caesar, with an Account of His Early Friends, Enemies, and Rivals: Part I, „Transactions of the Royal Historical Society” 1907, 1, s. 33-97.

Lovano M., The Age of Cinna: Crucible of Late Republican Rome, Stuttgart 2002.

Kahn A.D., The Education of Julius Caesar. A Biography, a Reconstruction, New York 1986.

Kamm A., Julius Caesar. A Life, London-New York 2006.

Keaveney A., Sulla, Sulpicius and Caesar Strabo, „Latomus” 1979, 38, s. 451—460.

Keaveney A., Sulla. The Last Republican, London-Canberra 1982.

Keaveney A., Who were the Sullani?, „Klio” 1984, 66, s. 114-150.

Klebs E., Aurelia (248), w: Real-Encyclopädie der classischen Altertumswissenschaft, Bd. 2, Stuttgart 1896, szp. 2543.

Klebs E., Aurelius, w: Real-Encyclopädie der classischen Altertumswissenschaft, Bd. 2, Stuttgart 1896, szp. 2431.

Konrad C.F., Cotta off Mellaria and the Identities of Fufidius, „Classical Philology” 1989, 84, s. $119-129$.

Korolenkov A.W. [Короленков A.В.], Сулла и Цезарь: противостояние, „Studia Historica” 2013, 13, s. 114-135.

Lanzani C., Lucio Cornelio Silla dittatore, Milano 1936.

Liubimova O.W., Taryverdieva S.E. [Любимова О.В., Таривердиева С.Э.], Конфликт Цезаря с Суллой: приключенческий роман, пропаганда или действительность?, „Studia Historica” 2015, 14, s. 66-97.

Le Bohec Y., Cezar, przeł. M. Kropiwnicka, Warszawa 2003.

Leone M., Il problema del flaminato di Cesare, w: Studi di storia antica offerti a Eugenio Manni, Rome 1973, s. 193-212.

Linderski J., Roman Questions II, Stuttgart 2007.

Liou Gille B., César, „flamen Dialis destinatus”, „Revue des Études Anciennes” 1999, 101, s. 433-459.

Madejski P., Sullańskie proskrypcje a zemsta w Rzymie, w: Świat starożytny. Państwo i społeczeństwo, red. R. Kulesza, M. Stępień, E. Szabat, M. Daszuta, Warszawa 2013, s. 239-247.

Meier C., Caesar, München 1986. 
Münzer F., Cornelia (413), w: Real-Encyclopädie der classischen Altertumswissenschaft, Hlb. 7, Stuttgart 1900, szp. 1596.

Münzer F., Cornelius Phagita, w: Real-Encyclopädie der classischen Altertumswissenschaft, Hlb. 7, Stuttgart 1900, szp. 1419.

Münzer F., Iulia (541), w: Real-Encyclopädie der classischen Altertumswissenschaft, Hlb. 19, Stuttgart 1918, szp. 892.

Münzer F., Iulia (547), w: Real-Encyclopädie der classischen Altertumswissenschaft, Hlb. 19, Stuttgart 1918, szp. 894-895.

Münzer F., C. Marius (15), w: Real-Encyclopädie der classischen Altertumswissenschaft, Hlb. 28, Stuttgart 1930, szp. 1811-1817.

Pelling C., The First Biographers: Plutarch and Suetonius, w: A Companion to Julius Caesar, ed. M. Griffin, [Blackwell Publishing] 2009, s. 252-266.

Peter H., Die Quellen Plutarchs in den Biographieen der Römer, Halle 1895.

Pötscher W., Flamen Dialis, „Mnemosyne” 1968, 21, s. 215-239.

Rice Holmes T., The Roman Republic and the Founder of the Empire, vol. 1, Oxford 1923.

Ridley R.T., The Dictator's Mistake: Caesar's Escape from Sulla, „Historia” 2000, 49, s. 211-229.

Scheid J., Kapłan, w: Człowiek Rzymu, red. A. Giardina, przeł. P. Bravo, Warszawa 1997.

Southern P., Caesar, [Tempus Publishing] 2001.

Sumner G.V., A Note on Julius Caesar's Great Grandfather, „Classical Philology” 1976, 71, s. 341-344.

Syme R., Roman Revolution, Oxford 1939.

Tatum W.J., Always I am Caesar, [Blackwell Publishing] 2008.

Taylor L.R., Caesar and the Roman Nobility, „Transactions and Proceedings of the American Philological Association" 1942, 73, s. 1-24.

Taylor L.R., Caesar's Early Career, „Classical Philology” 1941, 36, s. 113-132.

Towned G.B., C. Oppius on Julius Caesar, „The American Journal of Philology” 1987, 108, s. 325-342.

Walter G., Cezar, przeł. D. Wilanowska, Warszawa 1983.

Tomasz Ładoń

The Genesis and Context of the Conflict between G. Julius Caesar and L. Cornelius Sulla

Summary

The author of this article has focused on two issues. The first concerns the early activity of Gaius Julius Caesar and his position on the conflict between Lucius Cornelius Sulla and Gaius Marius. Caesar was then in close relations with the Cynno-Marian camp at the time, as evidenced by his marriage to Cornelia, daughter of Lucius Cornelius Cinna, and his appointment as a priest of Jupiter. In the second half of the article, Tomasz Ładon analyses the conflict Sulla and Caesar after the end of the first civil war. Ładon describes the causes and the course of this conflict and goes on to conclude that Caesar, despite his initial disagreements with Sulla, not only was not persecuted, but reached a compromise with him during the Sullan restauration in the 70s of the first century BC., which allowed him to start building his own career.

Key words: Caesar, Sulla, proscriptions, conflict, dictatorship 